\title{
A magyar lakosság egészségi állapota 2000 és 2010 között
}

\author{
Baji Petra dr. ${ }^{1,2}$ - Brodszky Valentin dr. ${ }^{1}$ - Rencz Fanni dr. ${ }^{1,3}$ \\ Boncz Imre dr. ${ }^{4}$. Gulácsi László dr. ${ }^{1 *}$ - Péntek Márta dr. ${ }^{1,5 *}$ \\ ${ }^{1}$ Budapesti Corvinus Egyetem, Egészségügyi Közgazdaságtan Tanszék, Budapest \\ ${ }^{2}$ CERGE-EI, Prága, Csehország \\ ${ }^{3}$ Semmelweis Egyetem, Klinikai Orvostudományok Doktori Iskola, Budapest \\ ${ }^{4}$ Pécsi Tudományegyetem, Egészségbiztosítási Intézet, Pécs \\ ${ }^{5}$ Pest Megyei Flór Ferenc Kórház, Reumatológiai és Fizioterápiás Osztály, Kistarcsa
}

\begin{abstract}
Bevezetés: Hazánkban 2000-ben készült olyan felmérés, amely a lakosság egészségi állapotát vizsgálta EQ-5D kérdőívvel. Célkitüzés: A lakosság egészségi állapotának felmérése különböző szociodemográfiai jellemzők szerint és összehasonlítás a 2000-es adatokkal. Módszer: 2010-ben egy nemzetközi kutatás keretében internetalapú keresztmetszeti kérdőíves vizsgálatot végeztek a lakosság körében az EQ-5D-3L kérdőívvel. Eredmények: 2281 válaszadó (nők: $62,3 \%)$ töltötte ki a kérdőívet, az átlagéletkor 40,8 év volt. Az EQ-5D-index 0,902 (18-24 év) és 0,795 (65+) között alakult. Szignifikáns összefüggést találtak az életminőség és a nem, életkor, iskolázottság, jövedelem között $(\mathrm{F}(4,1967)$ $=35,12, \mathrm{p}=0,000)$. Az eredmények nem térnek el szignifikánsan a 2000-es felmérés eredményeitől a 18-24 éves korcsoportot kivéve, ahol alacsonyabb értékeket kaptak. Következtetések: Miközben 2000 és 2010 között a lakosság várható élettartama 3 évvel nőtt, az egészségi állapota nem javult, sőt a 18-24 év közötti korosztályban romolhatott is, nemzetközi összehasonlításban pedig továbbra is a legrosszabbak közé tartozik. Nem csökkentek az egészségi állapottal összefüggő egyenlőtlenségek jövedelem és iskolai végzettség szerint. Orv. Hetil., 2015, 156(50), 20352044.
\end{abstract}

Kulcsszavak: egészségi állapot, EQ-5D, EuroVaQ, Magyarország

\section{Health state of the Hungarian population between 2000-2010}

Introduction: So far, the latest survey which used the EQ-5D questionnaire to measure the health status of the Hungarian population was carried out in 2000. Aim: To explore the health state of the Hungarian population by sociodemographic characteristics, and to compare it with the results from 2000. Method: As part of an international research project, a cross-sectional, online survey was carried out among the general population in 2010 using the EQ-5D-3L questionnaire. Results: In total, 2281 respondents (female: $62.3 \%$ ) completed the questionnaire with an average age of 40.8 years. The EQ-5D score ranged from 0.902 (in age-group 18-24) to 0.795 (65+). The authors found significant association between the EQ-5D score and all the socio-demographic variables (gender, age, education, income) included in the regression model $\left(\mathrm{F}\left({ }_{4,1967}\right)=35.12, \mathrm{p}=0.000\right)$. The results did not differ significantly from the health survey in 2000, except for the youngest population group (age 18-24), where significantly lower scores were found in the sample. Conclusions: While life expectance increased by 3 years between 2000 and 2010 , the health status of the Hungarian population did not change significantly, and might even decreased among young adults in fact. Inequalities in health status by income and education remain significant. In international comparison, the health status of the Hungarian population remains among the worst ones.

Keywords: health status, EQ-5D, EuroVaQ, Hungary

Baji, P., Brodszky, V., Rencz, F., Boncz, I., Gulácsi, L., Péntek, M. [Health state of the Hungarian population between 2000-2010]. Orv. Hetil., 2015, 156(50), 2035-2044.

(Beérkezett: 2015. augusztus 28.; elfogadva: 2015. szeptember 24.)

*A két szerző egyenlő arányban vett részt a munkában. 


\section{Rövidítések}

EuroVaQ = European Value of a Quality Adjusted Life Year; EQ-5D = egészségi állapotot mérő kérdőív; EQ VAS = vizuális analóg skála; OLEF = Országos Lakossági Egészség Felmérés; $\mathrm{QALY}=$ (quality adjusted life year) életminőséggel korrigált életév

$\mathrm{Az}$ általános egészségi állapot mérésére az EQ-5D kérdóív az egyik leggyakrabban alkalmazott mérce, amelyet 25 éve használnak [1]. Az EQ-5D az egészség öt általános aspektusát vizsgálja, nevezetesen a mozgékonyságot, az önellátást, a szokásos tevékenységek elvégzésének nehezítettségét, valamint a fájdalom/rossz közérzet és a szorongás/lehangoltság területén jelentkező problémákat. Általános jellegéből adódóan lehetővé teszi az általános lakosság és különböző betegségekben szenvedő betegek egészségi állapotának felmérését és összehasonlítását, valamint a különböző betegcsoportok közötti összehasonlítást. További előnye, hogy 170 nyelven hivatalos nyelvi verzió készült belóle, így nemzetközi vizsgálatokban is alkalmazható. Az EQ-5D-eredmények továbbá fontos inputjai az egészség-gazdaságtani elemzésekben az életminőséggel korrigált életév (quality adjusted life year - QALY) kiszámolásának [2].

Különböző betegségekben végzett hazai keresztmetszeti kérdőíves vizsgálatokban többször alkalmazásra került az EQ-5D kérdőív a betegek egészségi állapotának felmérésére, mint például a psoriasis $[3,4,5,6]$, rheumatoid arthritis $[7,8,9,10]$, jóindulatú prosztatamegnagyobbodás [11], epilepszia [12], perifériás artériás obliteratív érbetegség [13], sclerosis multiplex [14], hiperaktív hólyag szindróma [15], szkizofrénia [16], krónikus obstruktív tüdőbetegség (COPD) [17, 18], demencia [19], Parkinson-kór [20, 21, 22], arthritis psoriatica $[5,23]$, asztma $[17,24]$ és 2-es típusú cukorbetegség [25] esetében.

Az általános lakosság körében Magyarországon 2000ben készült olyan felmérés ${ }^{1}$, amely az EQ-5D kérdóívet alkalmazta, 5503 fós mintán [26, 27]. Tíz évvel késóbb, 2010-ben a European Value of a Quality Adjusted Life Year (EuroVaQ) ${ }^{2}$ nemzetközi kutatás keretében 2281 válaszadó töltötte ki az EQ-5D kérdőívet, szintén az általános lakosság körében. Közleményünkben ezeket a kutatási eredményeinket mutatjuk be a fóbb szociodemográfiai jellemzők (kor, nem, életkor, jövedelem és lakhely, iskolázottság) alapján, majd a 2010-es adatokat öszszevetjük a 2000-es felmérés eredményeivel.

\footnotetext{
'Országos Lakossági Egészség Felmérés (OLEF 2000). A felméréshez 7000 fơt választottak ki véletlenszerűen a magyar lakosságból regiszterek alapján, akiket kérdezőbiztosok kerestek fel otthonukban. Összesen 5503-an töltötték ki a kérdőívet. A szerzők szerint a minta kor és nem szerint reprezentatív a magyar lakosságra.
}

${ }^{2}$ Információ: http://research.ncl.ac.uk/eurovaq/

\section{Módszer}

\section{EQ-5D kérdöin}

Az EQ-5D egy önkitöltős, az általános egészségi állapotot felmérő kérdőív, amely 2 részből áll [1]. Az EQ-5D leíró része az egészség 5 dimenzióját (mozgékonyság, önellátás, szokásos tevékenységek, fájdalom/rossz közérzet, szorongás/lehangoltság) vizsgálja és mindegyikre háromféle válaszadás lehetséges (ez az úgynevezett EQ5D-3L verzió, továbbiakban EQ-5D): nincs probléma, némi probléma/mérsékelt, súlyos probléma/képtelen rá. ${ }^{3}$ Összesen 243 különböző egészségi állapot írható le a kérdőívvel. Az egészségi állapotokhoz rendelhető hasznosságértékeket (az adott egészségi állapotok preferáltságát kifejező értékek) Dolan és mtsai úgynevezett időalku módszerrel határozták meg 3000 fós brit reprezentatív lakossági minta alapján, így az EQ-5D-index értéktartománya $(-0,594)-1$, a magasabb érték jobb egészségi állapotra utal [28].

Az EQ-5D kérdőív második része egy „egészséghőmérő", amely az általános egészségi állapotot méri vizuális analóg skála segítségével (EQ VAS). Értéktartománya $0-100$, amelyen a 100 az elképzelhető legjobb, a 0 az elképzelhető legrosszabb egészségi állapotot jelenti $[1,29]$.

\section{EuroVaQfelmérés}

Online kérdőíves felmérés zajlott 10 országban (Dánia, Egyesült Királyság, Franciaország, Hollandia, Lengyelország, Magyarország, Norvégia, Palesztina, Spanyolország, Svédország) az EuroVaQ program keretében. A felmérés elsődleges célja annak feltárása volt, hogy a lakosság pénzben kifejezve mennyire értékel egy teljes egészségben eltöltött életévet (quality adjusted life year - QALY), az értékelést különböző hipotetikus egészségi állapotokra végezték el [30].

A cél az országonként reprezentatív minta elérése volt, ennek megfelelően kvóták kerültek kialakításra kor, nem és lakóhely szerint.

A felmérés során a hazai válaszadók az EQ-5D kérdőív validált magyar nyelvű verzióját is kitöltötték. A válaszok alapján az egészségi állapotokhoz tartozó EQ-5D-indexeket a brit hasznossági súlyok alapján állítottuk elő [28] a 2000-ben végzett felméréshez hasonlóan, hiszen hazai hasznossági súlyok továbbra sem állnak rendelkezésre. Az EQ VAS-t a válaszadók egy másik almintája töltötte ki, azonban közleményünkben ezekkel az adatokkal nem foglalkozunk, csak az EQ-5D-index-értékek bemutatását és elemzését tűztük ki célul.

${ }^{3}$ Itt jegyezzük meg, hogy azóta kifejlesztették a kérdőív ötféle válaszadási verzióját, így a korábbi az EQ-5D-3L, ez utóbbi pedig az EQ-5D-5L elnevezést kapta. Tanulmányunkban az EQ-5D-3L-t használtuk és a továbbiakban az EQ-5D megnevezést használjuk. 


\section{Statisztikai elemzés}

Az EQ-5D-index-értékeket kor és nem szerinti bontásban közöljük, valamint a populációs nemi arányokkal számított súlyozott átlagot is kiszámítottuk. Az EQ-5Dindex iskolai végzettség és jövedelmi decilisenkénti eltérésének elemzését varianciaelemzéssel (ANOVA) végeztük. Az életminőség és a válaszadók társadalmi és demográfiai jellemzőinek kapcsolatát többváltozós lineáris regressziós elemzéssel vizsgáltuk. A modellben a függő (eredmény) változó az EQ-5D-index, míg a magyarázó változók az életkor, nem, a válaszadó iskolai végzettsége (van-e felsőfokú végzettsége, egyetem vagy fóiskola), és a háztartás havi nettó ekvivalens jövedelme ${ }^{4}$. A 2010-es és a 2000-es EQ-5D-index-eredmények korcsoport és nem szerinti összehasonlítását Student-féle kétoldalú t-próbával végeztük. Az elemzésekhez 5\%-os szignifikanciaszintet alkalmaztunk. A számításokhoz és az elemzéshez Stata 11 szoftvert használtunk.

\section{Eredmények}

\section{A minta}

Összesen 2281 hazai válaszadó töltötte ki a kérdőívet, a válaszadók $62,3 \%$-a nő volt, az átlagéletkor a mintában 40,8 év (minimum: 18 év, maximum: 84 év, $S D=13,3$ év). A minta nem, korcsoport, iskolai végzettség, lakóhely, foglalkozás szerinti megoszlását az 1. táblázat mutatja be. Az EQ-5D kérdőívet minden válaszadó kitöltötte.

\section{EQ-5D-eredmények}

A legtöbb problémát a fájdalom/rossz közérzet dimenzióban jelezték a válaszadók, 35\%-uk jelzett mérsékelt, $2 \%$-uk nagyon erôs fájdalmat/rossz közérzetet. Ezt követte a szorongás/lehangoltság dimenzió, ahol a mérsékelt és nagyon erős szorongást/lehangoltságot jelzők aránya rendre $29 \%$ és 3\%. A mozgékonyság dimenzióban a válaszadók 19\%-a jelzett némi problémát a járással, 1\%-a ágyhoz kötöttséget. A szokásos tevékenységek elvégzésében a válaszadók $11 \%$-a jelzett némi problémát, $3 \%$ pedig képtelen elvégezni olyan szokásos tevékenységeit, mint a például munka, tanulás, házimunka, családi vagy szabadidős tevékenységek. Az önellátás a válaszadók 4\%-ának jelentett némi problémát és $3 \%$ képtelen az önellátásra. A problémát jelzók arányát a 2. táblázat szemlélteti korcsoport és nem szerinti bontásban.

${ }^{4} \mathrm{Az}$ OECD módszertana alapján számított ekvivalens jövedelem, amely 1-es súllyal veszi figyelembe az egy háztartásban élő első személyt, 0,7-es súllyal minden további felnóttet.
1. táblázat | A válaszadók fơbb demográfiai jellemzői

\begin{tabular}{|c|c|c|c|c|}
\hline $\begin{array}{l}\text { Jellemzők } \\
\text { ( } \mathrm{N} \text { = válaszadók száma) }\end{array}$ & $\mathrm{N}$ & $\%$ & Átlag & Szórás \\
\hline $\mathrm{Nem}$ & 2281 & $100 \%$ & & \\
\hline Nó & 1422 & $62,3 \%$ & - & - \\
\hline Férfi & 859 & $37,7 \%$ & - & - \\
\hline Életkor, év & 2281 & $100 \%$ & 40,8 & 13,3 \\
\hline $18-24$ & 297 & $13,0 \%$ & - & - \\
\hline $25-34$ & 566 & $24,8 \%$ & - & - \\
\hline $35-44$ & 498 & $21,8 \%$ & - & - \\
\hline $45-54$ & 509 & $22,3 \%$ & - & - \\
\hline $55-64$ & 337 & $14,8 \%$ & - & - \\
\hline $65+$ & 74 & $3,2 \%$ & - & - \\
\hline \multicolumn{5}{|l|}{ Lakbely, régió } \\
\hline Budapest & 460 & $20,2 \%$ & - & - \\
\hline Pest megye & 316 & $13,9 \%$ & & \\
\hline Közép-Dunántúl & 278 & $12,2 \%$ & - & - \\
\hline Nyugat-Dunántúl & 179 & $7,8 \%$ & - & - \\
\hline Dél-Dunántúl & 221 & $9,7 \%$ & - & - \\
\hline Észak-Magyarország & 265 & $11,6 \%$ & - & - \\
\hline Észak-Alföld & 264 & $11,6 \%$ & - & - \\
\hline Dél-Alföld & 298 & $13,1 \%$ & - & - \\
\hline $\begin{array}{l}\text { Háztartás jövedelme, nettó } \\
\text { Ft/év }(N=1973)\end{array}$ & - & - & 2649784 & 1703574 \\
\hline $\begin{array}{l}\text { A válaszadó jövedelme, } \\
\text { nettó Ft/hó }(N=1200)\end{array}$ & - & - & 156534 & 467154 \\
\hline $\begin{array}{l}\text { A válaszadó háztartásának } \\
\text { havi ekvivalens jövedelme, } \\
\text { nettó Ft/hó }(N=1972)\end{array}$ & - & - & 129479 & 91578 \\
\hline \multicolumn{5}{|l|}{ Iskolai végzettség } \\
\hline Általános iskola & 45 & $2,0 \%$ & - & - \\
\hline Szakiskola & 186 & $8,2 \%$ & - & - \\
\hline Szakközépiskola & 485 & $21,3 \%$ & - & - \\
\hline Gimnázium & 331 & $14,5 \%$ & - & - \\
\hline $\begin{array}{l}\text { Főiskola, felsőfokú } \\
\text { szakképzés }\end{array}$ & 833 & $36,5 \%$ & - & - \\
\hline Egyetem & 401 & $17,6 \%$ & - & - \\
\hline \multicolumn{5}{|l|}{ Foglalkoztatottság } \\
\hline Főállásban foglalkoztatott & 1315 & $57,7 \%$ & - & - \\
\hline $\begin{array}{l}\text { Részmunkaidőben } \\
\text { foglalkoztatott } \\
\text { (kevesebb mint } \\
32 \text { óra/hét) }\end{array}$ & 133 & $5,8 \%$ & - & - \\
\hline $\begin{array}{l}\text { Nyugdíjas/ } \\
\text { rokkantnyugdíjas / } \\
\text { munkaképtelen }\end{array}$ & 349 & $15,3 \%$ & - & - \\
\hline Tanuló & 147 & $6,4 \%$ & - & - \\
\hline $\begin{array}{l}\text { Nem dolgozik/munkát } \\
\text { keres }\end{array}$ & 213 & $9,3 \%$ & - & - \\
\hline Háztartásbeli & 124 & $5,4 \%$ & - & - \\
\hline
\end{tabular}

Magyarázat: *Az OECD módszertana alapján számított ekvivalens jövedelem, amely 1 -es súllyal veszi figyelembe az egy háztartásban élő első személyt, 0,7-es súllyal minden további felnőttet, és 0,5-ös súllyal a gyermekeket [31]. 


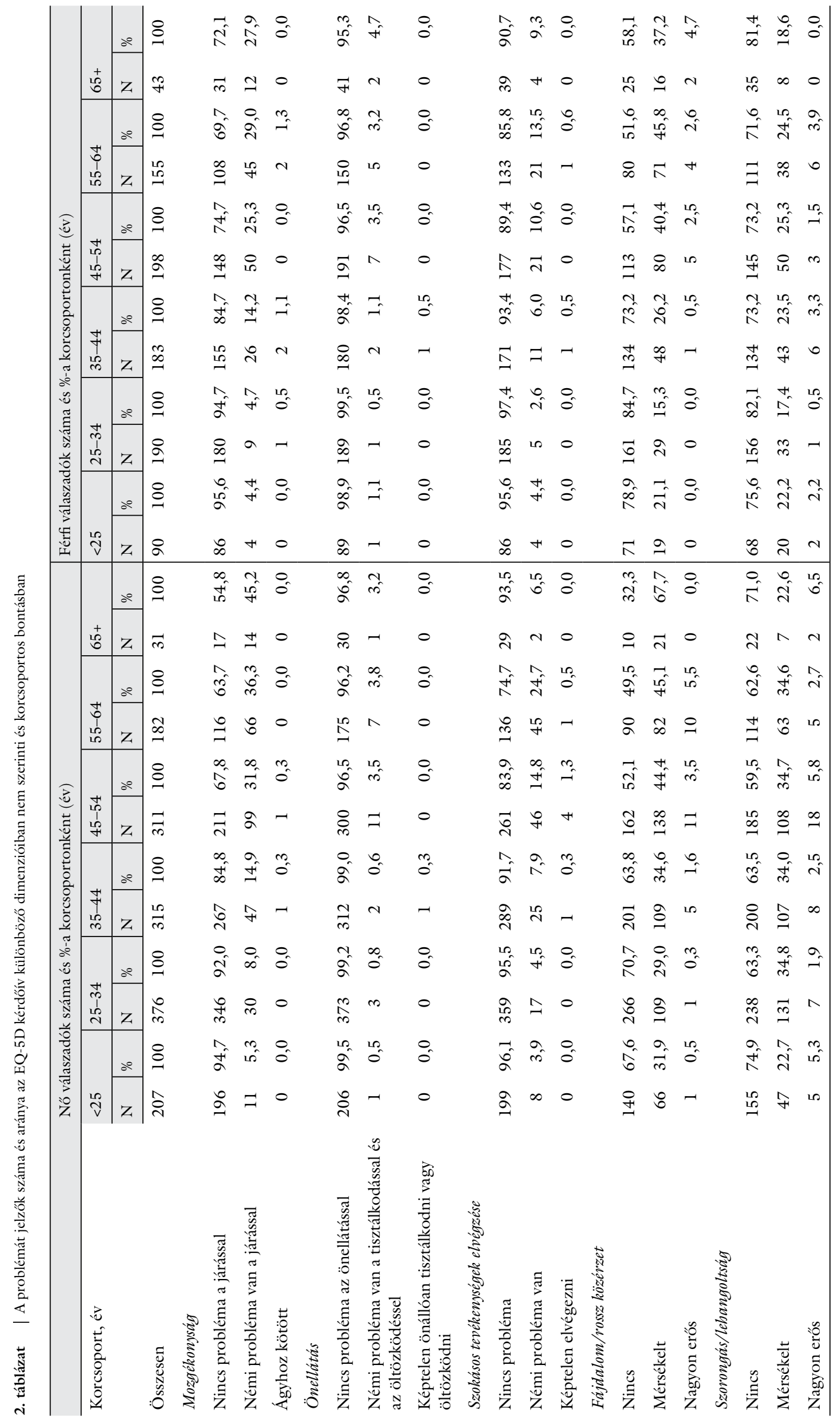




\section{EQ-5D-index}

Az EQ-5D kérdőív leíró részéből számított EQ-5D-index-értékeket a 3. táblázat tartalmazza 5 és 10 éves korcsoportos bontásban. A populációs nemi arányokkal számolt életminőség-eredmények korcsoportokra rendre $0,902(\mathrm{SD}=0,149)$ a $18-24$ éves korcsoportban, 0,910 $(\mathrm{SD}=0,142)$ a $25-34$ évesek közt, 0,865 $(\mathrm{SD}=0,195)$ a 35-44 évesekre, $0,813(\mathrm{SD}=0,226)$ a 45-54 évesekre, $0,796(\mathrm{SD}=0,241)$ az 55-64 évesekre és $0,795(\mathrm{SD}=$ $0,197)$ a 65 év feletti korosztályban.

A nơk egészségi állapota minden kategóriában roszszabb, mint a férfiaké, valamint mindkét nemnél megfi- gyelhető az egészségi állapot rosszabbodása az életkor növekedésével.

Az EQ-5D-index és az iskolai végzettség összefüggéseit a 1 . ábra szemlélteti. Az iskolai végzettség és az EQ-5D-index értékei között szignifikáns kapcsolatot találunk $\left(\mathrm{F}_{(5,2275)}=19,02, \mathrm{p}<0,001\right)$. A legalacsonyabb érték az általános iskolát végzetteké volt $(0,669, \mathrm{SD}=$ 0,278), míg a legmagasabb a föiskolai $(0,878, \mathrm{SD}=$ $0,187)$, valamint az egyetemi végzettségúeké $(0,886$; $0,152)$. A post-hoc elemzés eredményei szerint az egészségi állapot minden csoportban szignifikánsan különbözik, a fóiskolai és az egyetemi végzettségúeket kivéve, ahol a különbség statisztikailag nem szignifikáns $\left(\mathrm{F}_{(1,2275)}\right.$ $=0,45, \mathrm{p}=0,505)$. A szakközépiskolai végzettségúek

3. táblázat |Az EQ-5D-index értékei nemek szerint öt- és tízéves korcsoportos bontásban

\begin{tabular}{|c|c|c|c|c|c|c|c|c|}
\hline $\begin{array}{l}\text { Korcsoport, } \\
\text { év }\end{array}$ & $\begin{array}{l}\text { Férfi } \\
\text { átlag/ } \\
\text { szórás/ } \\
\mathrm{N}\end{array}$ & $\begin{array}{l}\text { Nő } \\
\text { átlag/ } \\
\text { szórás/ } \\
\text { N }\end{array}$ & $\begin{array}{l}\text { Összesen } \\
\text { átlag/ } \\
\text { szórás/ } \\
\mathrm{N}\end{array}$ & $\begin{array}{l}\text { A populációs } \\
\text { nemi } \\
\text { arányokkal } \\
\text { súlyozott } \\
\text { átlag*/ } \\
\text { szórás/ } \\
\text { N }\end{array}$ & $\begin{array}{l}\text { Férfi } \\
\text { átlag/ } \\
\text { szórás/ } \\
\mathrm{N}\end{array}$ & $\begin{array}{l}\text { Nő } \\
\text { átlag/ } \\
\text { szórás/ } \\
\text { N }\end{array}$ & $\begin{array}{l}\text { Összesen } \\
\text { átlag/ } \\
\text { szórás/ } \\
\mathrm{N}\end{array}$ & $\begin{array}{l}\text { A populációs } \\
\text { nemi } \\
\text { arányokkal } \\
\text { súlyozott } \\
\text { átlag* / } \\
\text { szórás/ } \\
\text { N }\end{array}$ \\
\hline $18-24$ & $\begin{array}{l}0,913 \\
0,139 \\
90\end{array}$ & $\begin{array}{l}0,890 \\
0,158 \\
207 \\
\end{array}$ & $\begin{array}{l}0,897 \\
0,153 \\
297 \\
\end{array}$ & $\begin{array}{l}0,902 \\
0,149 \\
297 \\
\end{array}$ & $\begin{array}{l}0,913 \\
0,139 \\
90 \\
\end{array}$ & $\begin{array}{l}0,890 \\
0,158 \\
207\end{array}$ & $\begin{array}{l}0,897 \\
0,153 \\
297 \\
\end{array}$ & $\begin{array}{l}0,902 \\
0,149 \\
297 \\
\end{array}$ \\
\hline $25-29$ & $\begin{array}{l}0,933 \\
0,124 \\
86\end{array}$ & $\begin{array}{l}0,933 \\
0,124 \\
86\end{array}$ & $\begin{array}{l}0,897 \\
0,153 \\
297\end{array}$ & $\begin{array}{l}0,897 \\
0,145 \\
286\end{array}$ & \multirow{2}{*}{$\begin{array}{l}0,936 \\
0,125 \\
190\end{array}$} & \multirow{2}{*}{$\begin{array}{l}0,883 \\
0,153 \\
376\end{array}$} & \multirow{2}{*}{$\begin{array}{l}0,901 \\
0,146 \\
566\end{array}$} & \multirow{2}{*}{$\begin{array}{l}0,910 \\
0,142 \\
566\end{array}$} \\
\hline $30-34$ & $\begin{array}{l}0,939 \\
0,127 \\
104\end{array}$ & $\begin{array}{l}0,881 \\
0,151 \\
200\end{array}$ & $\begin{array}{l}0,897 \\
0,145 \\
286\end{array}$ & $\begin{array}{l}0,905 \\
0,148 \\
280\end{array}$ & & & & \\
\hline $35-39$ & $\begin{array}{l}0,889 \\
0,199 \\
99\end{array}$ & $\begin{array}{l}0,885 \\
0,156 \\
176\end{array}$ & $\begin{array}{l}0,905 \\
0,148 \\
280\end{array}$ & $\begin{array}{l}0,883 \\
0,194 \\
250\end{array}$ & \multirow{2}{*}{$\begin{array}{l}0,876 \\
0,199 \\
183\end{array}$} & \multirow{2}{*}{$\begin{array}{l}0,854 \\
0,191 \\
315\end{array}$} & \multirow{2}{*}{$\begin{array}{l}0,862 \\
0,194 \\
498\end{array}$} & \multirow{2}{*}{$\begin{array}{l}0,865 \\
0,195 \\
498\end{array}$} \\
\hline $40-44$ & $\begin{array}{l}0,861 \\
0,198 \\
84\end{array}$ & $\begin{array}{l}0,880 \\
0,191 \\
151 \\
\end{array}$ & $\begin{array}{l}0,883 \\
0,194 \\
250\end{array}$ & $\begin{array}{l}0,841 \\
0,192 \\
248\end{array}$ & & & & \\
\hline $45-49$ & $\begin{array}{l}0,855 \\
0,180 \\
88\end{array}$ & $\begin{array}{l}0,830 \\
0,189 \\
164\end{array}$ & $\begin{array}{l}0,841 \\
0,192 \\
248\end{array}$ & $\begin{array}{l}0,846 \\
0,189 \\
187\end{array}$ & \multirow{2}{*}{$\begin{array}{l}0,841 \\
0,196 \\
198\end{array}$} & \multirow{2}{*}{$\begin{array}{l}0,786 \\
0,249 \\
311\end{array}$} & \multirow{2}{*}{$\begin{array}{l}0,807 \\
0,231 \\
509\end{array}$} & \multirow{2}{*}{$\begin{array}{l}0,813 \\
0,226 \\
509\end{array}$} \\
\hline $50-54$ & $\begin{array}{l}0,829 \\
0,208 \\
110\end{array}$ & $\begin{array}{l}0,838 \\
0,198 \\
99\end{array}$ & $\begin{array}{l}0,846 \\
0,189 \\
187\end{array}$ & $\begin{array}{l}0,785 \\
0,249 \\
322 \\
\end{array}$ & & & & \\
\hline $55-59$ & $\begin{array}{l}0,802 \\
0,257 \\
90\end{array}$ & $\begin{array}{l}0,762 \\
0,266 \\
212\end{array}$ & $\begin{array}{l}0,785 \\
0,249 \\
322\end{array}$ & $\begin{array}{l}0,781 \\
0,270 \\
203\end{array}$ & \multirow{2}{*}{$\begin{array}{l}0,812 \\
0,234 \\
155\end{array}$} & \multirow{2}{*}{$\begin{array}{l}0,782 \\
0,246 \\
182\end{array}$} & \multirow{2}{*}{$\begin{array}{l}0,796 \\
0,241 \\
337\end{array}$} & \multirow{2}{*}{$\begin{array}{l}0,796 \\
0,241 \\
337\end{array}$} \\
\hline $60-64$ & $\begin{array}{l}0,826 \\
0,199 \\
65\end{array}$ & $\begin{array}{l}0,765 \\
0,279 \\
113 \\
\end{array}$ & $\begin{array}{l}0,781 \\
0,270 \\
203 \\
\end{array}$ & $\begin{array}{l}0,817 \\
0,188 \\
134 \\
\end{array}$ & & & & \\
\hline $65-74$ & $\begin{array}{l}0,857 \\
0,178 \\
38\end{array}$ & $\begin{array}{l}0,765 \\
0,181 \\
30\end{array}$ & $\begin{array}{l}0,816 \\
0,184 \\
68\end{array}$ & $\begin{array}{l}0,803 \\
0,185 \\
68\end{array}$ & \multirow{2}{*}{$\begin{array}{l}0,844 \\
0,218 \\
43\end{array}$} & \multirow{2}{*}{$\begin{array}{l}0,766 \\
0,178 \\
31\end{array}$} & \multirow{2}{*}{$\begin{array}{l}0,811 \\
0,205 \\
74\end{array}$} & \multirow{2}{*}{$\begin{array}{l}0,795 \\
0,197 \\
148\end{array}$} \\
\hline $75+$ & $\begin{array}{l}0,742 \\
0,440 \\
5\end{array}$ & $\begin{array}{l}0,796 \\
- \\
1\end{array}$ & $\begin{array}{l}0,751 \\
0,394 \\
6\end{array}$ & $\begin{array}{l}0,778 \\
0,254 \\
6\end{array}$ & & & & \\
\hline
\end{tabular}

Megjegyzés: *A populációs nemi arányokat a 2011-es népszámlálás adataiból vettük. Forrás: KSH Népszámlálás 2011 - 3 . Országos adatok. http://www.ksh.hu/nepszamlalas/tablak_teruleti_00 


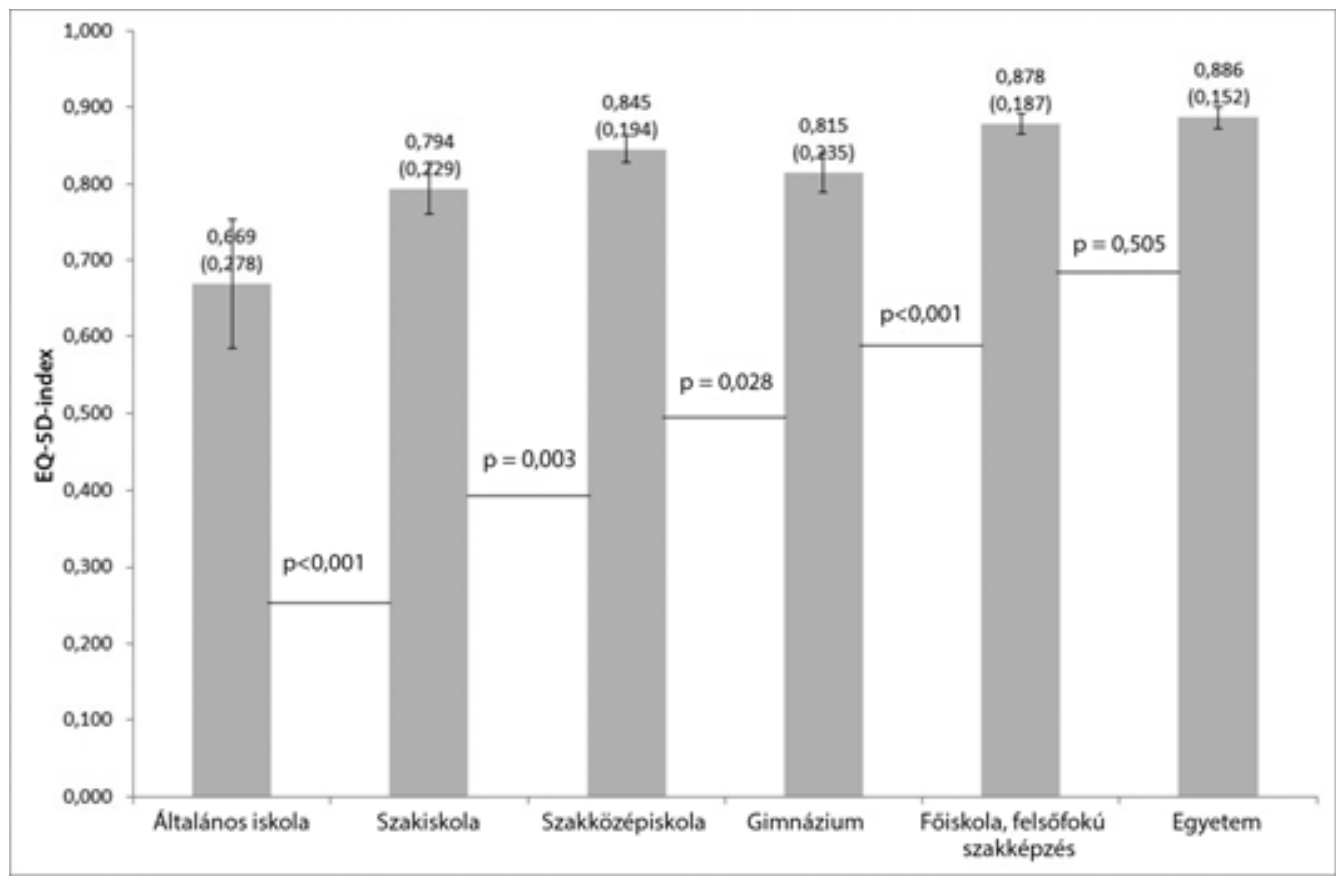

1. ábra

Az EQ-5D-értékek átlaga iskolai végzettség szerint

Magyarázat: Zárójelben a szórás szerepel. A függőleges szakaszok az átlag körüli 95\%-os konfidenciaintervallumot jelzik. A vízszintes vonalakon az együtthatók közti post-hoc teszt eredményeihez tartozó p-értékeket közöljük

egészségi állapota $(0,845, \mathrm{SD}=0,194)$ szignifikánsan jobb, mint a gimnáziumot végzetteké $(0,815, \mathrm{SD}=$ $0,235)\left(\mathrm{F}_{(1,2275)}=4,81, \mathrm{p}=0,028\right)$.
Az EQ-5D-index-eredményeket jövedelmi decilisenként is megvizsgáltuk. Az ANOVA teszt eredményei szerint szignifikáns a kapcsolat a jövedelmi helyzet és az

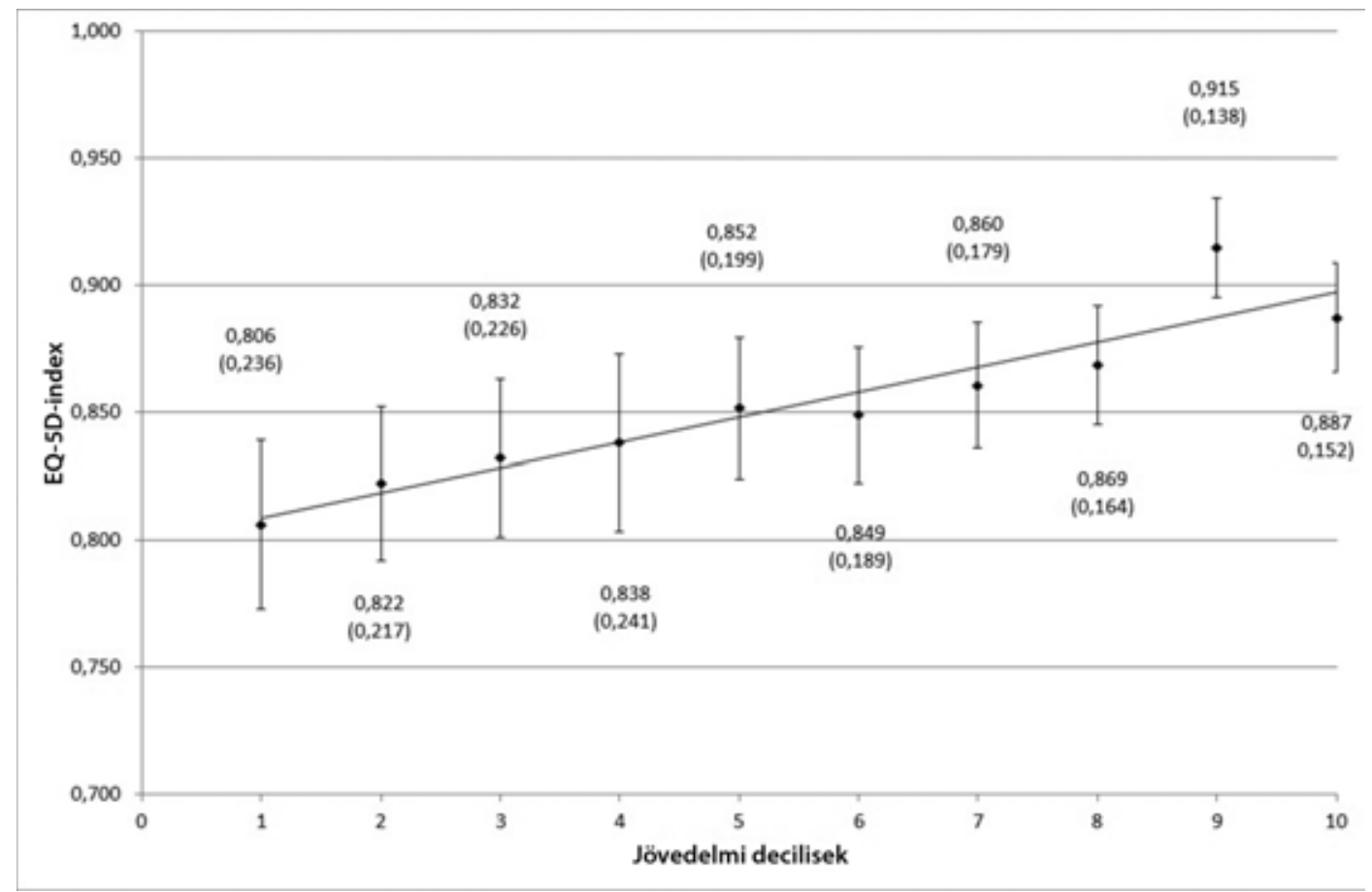

2. ábra

\footnotetext{
Az EQ-5D-értékek átlaga jövedelmi decilisek szerint

Magyarázat: Zárójelben a szórás szerepel. A szakaszok az átlag körüli 95\%-os konfidenciaintervallumot jelzik
} 
A többváltozós lineáris regresszió eredményei (eredményváltozó: EQ-5D-index)

\begin{tabular}{ll}
\hline Magyarázó változók & $\begin{array}{l}\text { Együttható } \\
(\text { standard hiba })\end{array}$ \\
\hline Nem (referencia = férfi) & $-0,042^{* * *}$ \\
& $(0,01)$ \\
Életkor (év) & $-0,003 * * *$ \\
& $(0,00)$ \\
Felsőfokú iskolai végzettség (referencia: & $0,047 * * *$ \\
középfokú vagy alacsonyabb) & $(0,01)$ \\
Válaszadó háztartásának jövedelme (havi & $0,002 * * *$ \\
nettó 10 ezer) & $(0,00)$ \\
Konstans & $0,961 * * *$ \\
& $(0,02)$ \\
\hline Mintaelemszám & 1972 \\
F-teszt & $\mathrm{F}_{(4,1967)}=35,12$ \\
& $\mathrm{p}=0,000$ \\
$\mathrm{R}^{2}$ & $\mathrm{R}^{2}=0,0752$ \\
\hline
\end{tabular}

$* * * \mathrm{p}<0,01$

egészségi állapot között $\left(\mathrm{F}_{(9,1962)}=5,17, \mathrm{p}<0,001\right)$. $\mathrm{Az}$ összefüggést a 2. ábra szemlélteti. Látható, hogy a jövedelem növekedésével az EQ-5D-index-érték enyhén növekszik.

\section{Regressziós elemzés eredményei}

A többváltozós lineáris regressziós elemzés eredményeit a 4. táblázat tartalmazza. Szignifikáns összefüggést találtunk az egészségi állapot (EQ-5D-index) és a modellbe bevont összes magyarázó változó (nem, életkor, iskolai végzettség, jövedelem) között $\left(\mathrm{F}_{(4,1967)}=35,12, \mathrm{p}=\right.$ 0,000). A nők EQ-5D-index-értéke átlagosan 0,04 ponttal alacsonyabb, mint a férfiaké. Az életkor növekedésével az EQ-5D-index átlagosan 0,003 pontot csökken évente. A felsőfokú végzettségűek körében szignifikánsan (átlagosan 0,047 ponttal) magasabb az EQ-5D-index, mint a középfokú vagy annál alacsonyabb végzettségúeknél. A jövedelem növekedésével is szignifikáns növekedést tapasztalhatunk az EQ-5D-indexben (plusz havi nettó 10000 Ft növekedés az életminőségindexben 0,002 pont növekedést jelent).

\section{A 2010-es és 2000-es eredmények összehasonlitása}

A 2010-es eredményeket összehasonlítottuk a 2000-es felmérés eredményeivel (3. ábra). Szignifikáns eltérést találtunk $(\mathrm{p}<0,05)$ a 2000-es és 2010-es eredmények között a 18-24 év közötti korcsoportban mind a férfiak $(\mathrm{t}=-2,6873, \mathrm{p}=0,0075)$, mind a nók között $(\mathrm{t}=$ $-3,3741, \mathrm{p}=0,0008)$, valamint az 55-64 éves korosztályban a nók között $(\mathrm{t}=2,4144, \mathrm{p}=0,0160)$. A többi korcsoportban nem találtunk szignifikáns eltérést. Jelentősebb különbség tapasztalható még az EQ-5D-indexértékekben a 65-74 éves korosztályban, de a különbség 5\%-os szignifikanciaszinten nem szignifikáns (a férfiaknál: $\mathrm{t}=1,8516, \mathrm{p}=0,0651$, a nóknél: $\mathrm{t}=1,3823, \mathrm{p}=$ $0,1676)$. A többi alcsoportban az eredmények nem tértek el szignifikánsan a 2000-es mintától ( $p>0,1)$.

A lineáris regressziós eredményeket tekintve mind az együtthatók előjele, mind a nagysága hasonló a korábbi 2000-es vizsgálat alapján közölt eredményekhez. Az

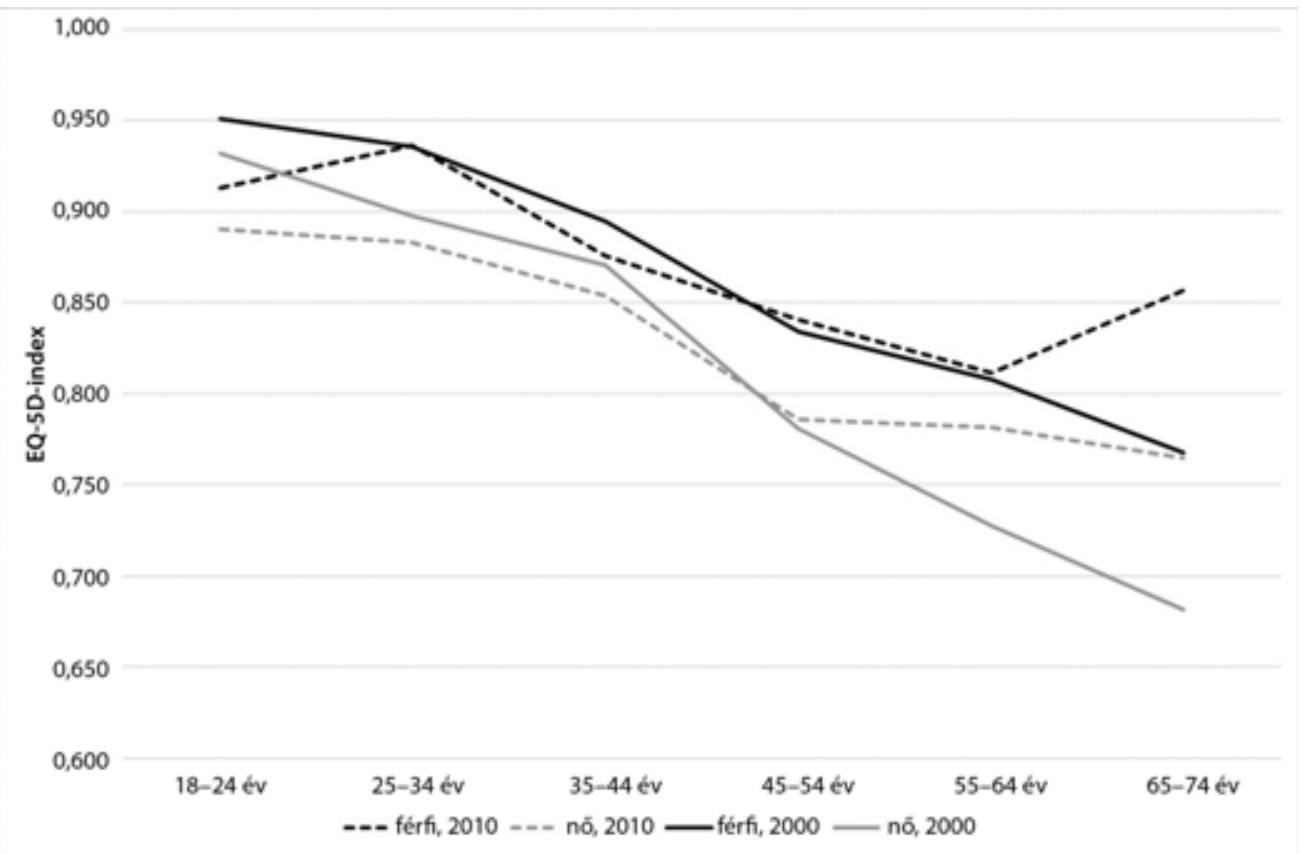

3. ábra | A 2010-es EuroVaQ és a 2000-es vizsgálat korcsoportos EQ-5D-index eredményeinek összevetése nemek szerint 
együtthatók nagyságában különbség csak a jövedelem hatásában látható. (10 000 Ft növekedés értéke az ekvivalens nettó háztartási jövedelemben a mintánkban 0,002 pont, míg a 2000-es mintában 0,006 pont.)

\section{Megbeszélés}

Tanulmányunkban bemutattuk egy 2010-ben, 2281 fó bevonásával végzett hazai egészségiállapot-felmérés eredményeit kor, nem, iskolai végzettség és jövedelmi helyzet szerinti bontásban.

A legtöbb problémát a lakosság a fájdalom/rossz közérzet és a szorongás/lehangoltság dimenzióban jelzett, a legkevesebb probléma pedig az önellátás terén mutatkozott.

A korábbi hazai és nemzetközi kutatások eredményeihez hasonlóan megállapítható, hogy az általános egészségi állapot a kor előrehaladtával mindkét nemnél roszszabbodik. Emellett a nők egészségi állapota minden korcsoportban szignifikánsan rosszabb, mint a férfiaké. Ezeket az összefüggéseket a többváltozós regressziós elemzés is alátámasztja.

A tanulmányban az egészségi állapot és a demográfiai jellemzők összefüggésén kívül az egészségi állapot és a társadalmi helyzet kapcsolatát is vizsgáltuk. Eredményeink azt mutatják, hogy az egészségi állapot szignifikáns kapcsolatban van az iskolai végzettséggel és a jövedelmi helyzettel. A felsófokú végzettségúek általános egészségi állapota szignifikánsan jobb, mint a középfokú vagy alacsonyabb végzettségúeké. Ezenkívül kimutatható, hogy a magasabb jövedelmúek egészségi állapota jobb az alacsonyabb jövedelmúekéhez képest.

Az eredményeinket a 2000-es felméréssel összehasonlítva elmondható, hogy a legfiatalabb korcsoport (18-24 év) kivételével az EuroVaQ 2010-es vizsgálatból származó EQ-5D-eredmények nem térnek el szignifikánsan. A 18-24 éves korcsoportban azonban jelen vizsgálatban mind a nők, mind a férfiak esetében szignifikánsan alacsonyabb értékeket mértünk, mint a 2000-es felmérés során. Az eltérést okozhatja a relatíve alacsony mintaelemszám, eredményeink alapján azonban nem vethető el az a hipotézis, miszerint a 18-24 éves korosztály egészségi állapota rosszabbodott 2000 és 2010 között. A mozgékonyság, a fájdalom/rossz közérzet és a szorongás/lehangoltság dimenziókban jeleztek több problémát a fiatalok 2010-ben. Jelentősebb eltérés mutatkozik még a 64 és 75 év közötti korosztály eredményeiben, a 2010-es EuroVaQ-mintában jobb eredmények születtek. Azonban ez a különbség a korcsoportban található alacsony mintaelemszámból adódóan nem volt szignifikáns. Megjegyzendő, hogy a korcsoportban a tervezettnél kevesebben töltötték ki a kérdőívet (nők - 87\%, férfiak - 67\%). Feltételezhető, hogy az online adatgyújtés miatt ebben a korosztályban az átlagnál magasabb jövedelemmel és/vagy iskolai végzettséggel rendelkezők, a jobb egészségi állapotban lévők töltötték ki a kérdőívet. Ez magyarázhatja a kedvezőbb eredményeket.
A többi korosztályban megállapítható, hogy a lakosság egészségi állapota EQ-5D-vel mérve nem változott szignifikánsan 2000 és 2010 között. Ez azt is jelenti, hogy a vizsgált korcsoportokban a lakosság egészségi állapota nem javult a két mérés között. Ugyanakkor a várható élettartam közel 3 évvel nőtt a vizsgált 10 éves időszak alatt. Az OECD adatai szerint a születéskor várható élettartam 2000-ben 71,9 év volt, míg 2010-ben 74,7 év [32].

A 2000-es felméréssel szemben, ahol az EQ-5D-index eredményei tízéves korcsoportos bontásban kerültek közlésre, tanulmányunkban az EQ-5D-értékeket ötéves korcsoportonként is bemutattuk. Úgy gondoljuk, hogy az ötéves korcsoportos bontásban közölt adatok jól felhasználhatók a klinikai és egészség-gazdaságtani elemzések során.

Mind a 2010-es EuroVaQ, mind a 2000-es felmérés eredményei szerint a magyar lakosság egészségi állapota elmarad a többi országétól. Tizennyolc ország adataihoz viszonyítva a magyar eredmények a legrosszabbak között találhatók Dél-Koreához, Thaiföldhöz és Szlovéniához hasonlóan [27].

Bár a 2010-es felmérés nem, kor és régió szerint reprezentatív minta elérését tûzte ki célul, a végső mintában a magyar lakossági arányokhoz képest a nők felül-, míg az idősebb korosztály alulreprezentált volt. Minden korcsoportban a lakossági arányokhoz képest több nő töltötte ki a kérdőívet, tehát ameddig a 2011-es népszámlálás adatai szerint a 20 év feletti lakosságban a nők aránya $58 \%$, a mintánkban ez 62\%. Ezenkívül a 2011-es népszámlálás adatai szerint a 65 év feletti korosztály aránya a 20 év feletti lakosságban 21\%, míg a mintánkban csak 3\%. Éppen ezért törekedtünk a felmérés adatainak kor és nem szerinti bontásban való közlésére, hiszen ezek megbízhatóbbak, mint a teljes populációra közölt eredmények.

Szintén az adatfelvétel módszertanából adódóan (internetalapú felmérés) feltételezhető, hogy a kérdőív nem jutott el minden társadalmi csoporthoz, feltehetóleg az alacsonyabb jövedelmú társadalmi csoportok alulreprezentáltak. Ez azt jelenti, hogy mintánk felülbecsli a lakosság életminőségét.

A 2000-es minta és a 2010-es saját mintánk összehasonlításához Szende [26] által közölt, brit hasznossági súlyokkal számított EQ-5D-index átlag- és standardhiba-értékeit használtuk fel. Az EQ-5D-index kiszámításához használt pontos mintaelemszámot egyik közlemény sem tartalmazta, ezért az összehasonlításhoz a teljes mintaelemszámot használtuk fel Szende alapján [27], annak ellenére, hogy az EQ-5D-index számításához használt mintaelemszám az egyes korcsoportokban feltételezhetően 1-2\%-kal kisebb volt, mint a teljes mintaelemszám. Szende és Németh 2003-as közleménye szerint az EQ-5D kérdőív esetében a válaszadási arány kevesebb, mint 100\% [26]. Eredményeink összevetésére Student-féle t-tesztet alkalmaztunk. A t-teszt feltételezi az adatok vizsgált változók szerinti normális eloszlását. 
A 2000-es mintában a normális eloszlás feltételezésével kapcsolatban nem találunk információt, mintánkban pedig a normalitása több változó esetében nem teljesül. Ebben az esetben javasolt a parametrikus tesztek helyett (például t-teszt) nemparametrikus tesztek elvégzése. Mivel azonban a 2000-es felmérésből csak a publikált átlagot és szórást ismertük, nemparaméteres teszt elvégzése nem állt módunkban.

A fent említett korlátok ellenére úgy gondoljuk, hogy kutatásunk új és valid eredményeket közöl a magyar lakosság egészségi állapotáról. Megállapításaink szerint az EQ-5D-vel mért egészségi állapot 2000 és 2010 között nem változott szignifikánsan, és nem zárható ki, hogy a 18-24 év közötti korosztályban még csökkent is. Továbbra is fennállnak a jövedelem és iskolai végzettség szerinti egészségi állapottal összefüggő egyenlőtlenségek. Nemzetközi összehasonlításban a hazai lakosság egészségi állapota továbbra is a legrosszabbak közé tartozik. A tanulmány fontos alapadatokat szolgáltat egészség-gazdaságtani elemzésekhez és népegészségügyi, illetve társadalombiztosítási támogatási döntéshozatalhoz.

Anyagi támogatás: Az EuroVaQ projektet az Európai Bizottság és a Közszolgáltatások Közgazdasági és Irányítási Kérdéseinek (Oktató, Továbbképző és Kutató) Központja Alapítvány támogatta, de nem felel a közölt információkért, a közlemény a szerzók meglátásait tükrözi.

Szerzői munkamegosztás: B. I., G. L., P. M.: A vizsgálat megtervezése és lefolytatása. B. P., B. V.: Statisztikai elemzések. B. P., B. V., G. L., R. F., B. I., P. M.: Az eredmények értékelése. B. P., G. L., P. M.: A kézirat összeállítása. A cikk végleges változatát valamennyi szerző elolvasta és jóváhagyta.

Érdekeltségek: G. L., P. M. az EuroVaQ európai kutatási program magyarországi kutatójaként dolgozott a vizsgálatban, B. I. a program felkért hazai szakértője volt.

\section{Köszönetnyilvánítás}

A szerzők köszönetüket fejezik ki az EuroVaQ nemzetközi kutatócsoportnak, amelynek tagjai: Newcastle University (Egyesült Királyság): Cam Donaldson, Rachel Baker, Mike Jones-Lee, Emily Lancsar, Helen Mason, Mark Pennington, Phil Shackley, John Wildman; Birzeit University (Palesztina): Rana A. Khatiba, Awad Mataria; Budapesti Corvinus Egyetem (Magyarország): Gulácsi László, Péntek Márta; Erasmus University Rotterdam (Hollandia): Werner Brouwer, Frans Rutten, Job van Exel; INSERM (Franciaország): Jean Paul Moatti, Christel Protiere, Stephane Luchini; Jagiellonian University Medical College (Lengyelország): Roman Topor Madry, Ewa Kocot, Darek Poznanski; Pablo de Olavide University (Spanyolország): Jose Luis Pinto Prades; Swedish Institute of Health Economics (Svédország): Ulf Persson; University of East (Egyesült Királyság): Angela Robinson; University of Southern Denmark (Dánia): Dorte Gyrd-Hansen, Mickael Bech, Trine Kjaer, Jytte Seested Nielsen; University of Tromso (Norvégia): Jan Abel Olsen; University of York (Egyesült Királyság): Andrea Manca.

\section{Irodalom}

[1] EuroQol Group: EuroQol - a new facility for the measurement of health-related quality of life. Health Policy, 1990, 16(3), 199208.

[2] Longworth, L., Yang, Y., Young, T., et al.: Use of generic and condition-specific measures of health-related quality of life in NICE decision-making: a systematic review, statistical modelling and survey. Health Technol. Assess., 2014, 18(9), 1-224.

[3] Herédi, E., Rencz, F., Balogh, O., et al.: Exploring the relationship between EQ-5D, DLQI and PASI, and mapping EQ-5D utilities: a cross-sectional study in psoriasis from Hungary. Eur. J. Health Econ., 2014, 15(Suppl. 1), S111-S119.

[4] Balogh, O., Brodszky, V., Gulácsi, L., et al.: Cost-of-illness in patients with moderate to severe psoriasis: a cross-sectional survey in Hungarian dermatological centres. Eur. J. Health Econ., 2014, 15(Suppl. 1), S101-S109.

[5] Rencz, F., Brodszky, V., Péntek, M., et al.: Disease burden of psoriasis associated with psoriatic arthritis in Hungary. [Arthritis psoriaticával társuló középsúlyos és súlyos psoriasis betegségterhe Magyarországon.] Orv. Hetil., 2014, 155(48), 1913-1921. [Hungarian]

[6] Rencz, F., Holló, P., Kárpáti, S., et al.: Moderate to severe psoriasis patients' subjective future expectations regarding health-related quality of life and longevity. J. Eur. Acad. Dermatol. Venereol., 2015, 29(7), 1398-1405.

[7] Péntek, M., Gulácsi, L., Rojkovich, B., et al.: Subjective health expectations at biological therapy initiation: a survey of rheumatoid arthritis patients and rheumatologists. Eur. J. Health Econ., 2014, 15(Suppl. 1), S83-S92.

[8] Péntek, M., Rojkovich, B., Czirják, L., et al.: Acceptability of less than perfect health states in rheumatoid arthritis: the patients' perspective. Eur. J. Health Econ., 2014, 15(Suppl. 1), S73-S82.

[9] Inotai, A., Rojkovich, B., Fülöp, A., et al.: Health-related quality of life and utility in patients receiving biological and non-biological treatments in rheumatoid arthritis. Rheumatol. Int., 2012, 32(4), 963-969.

[10] Péntek, M., Szekanecz, Z., Czirják, L., et al.: Impact of disease progression on health status, quality of life and costs in rheumatoid arthritis in Hungary. [A betegségprogresszió hatása az egészségi állapotra, életminőségre és költségekre rheumatoid arthritisben Magyarországon.] Orv Hetil., 2008, 149(16), 733741. [Hungarian]

[11] Rencz, F., Kovács, Á., Brodszky, V., et al.: Cost of illness of medically treated benign prostatic hyperplasia in Hungary. Int. Urol. Nephrol., 2015, 47(8), 1241-1249.

[12] Péntek, M., Bereczki, D., Gulácsi, L., et al.: Survey of adults living with epilepsy in Hungary: health-related quality of life and costs. [Epilepsziás felnőttek körében végzett felmérés Magyarországon.] Ideggyogy Sz., 2013, 66(7-8), 251-261. [Hungarian]

[13] Balogh, O., Péntek, M., Gulácsi, L., et al.: Quality of life and burden of disease in peripheral arterial disease: a study among Hungarian patients. [Magyarországi perifériás verőérbetegek életminőség és betegségteher vizsgálatának eredményei.] Orv. Hetil., 2013, 154(12), 464-470. [Hungarian]

[14] Péntek, M., Gulácsi, L., Rózsa, C., et al.: Health status and costs of ambulatory patients with multiple sclerosis in Hungary. [Magyarországi sclerosis multiplexes járóbetegek egészségi állapota és betegségköltsége.] Ideggyogy Sz., 2012, 65(9-10), 316-324. [Hungarian]

[15] Péntek, M., Gulácsi, L., Majoros, A., et al.: Health related quality of life and productivity of women with overactive bladder. [Hiperaktív hólyagszindrómával élő nők életminősége és munkaképessége.] Orv. Hetil., 2012, 153(27), 1068-1076. [Hungarian]

[16] Péntek, M., Harangozó, J., Égerbázi, A., et al.: Health related quality of life and disease burden of patients with schizophrenia in Hungary. [A szkizofréniával élő betegek egészséggel 
összefüggő életminősége és betegségterhe Magyarországon.] Psychiatr. Hung., 2012, 27(1), 4-17. [Hungarian]

[17] Szende, A., Leidy, N. K., Ståbl, E., et al.: Estimating health utilities in patients with asthma and COPD: evidence on the performance of EQ-5D and SF-6D. Qual. Life Res., 2009, 18(2), 267-272.

[18] Ágh, T., Inotai, A., Mészáros, Á.: Factors associated with medication adherence in patients with chronic obstructive pulmonary disease. Respiration, 2011, 82(4), 328-334.

[19] Érsek, K., Kovács, T., Wimo, A., et al.: Costs of dementia in Hungary. J. Nutr. Health Aging, 2010, 14(8), 633-639.

[20] Tamás, G., Gulácsi, L., Bereczki, D., et al.: Quality of life and costs in Parkinson's disease: a cross sectional study in Hungary. PLoS ONE, 2014, 9(9), el07704.

[21] Bokor, M., Szentesi, A.: The effect of Stalevo-dosing on quality of life of Parkinsonian patients with wearing-off. [A Stalevo-adagolás hatása a wearing off tüneteket mutató Parkinson-kóros betegek életminőségére.] Ideggyogy Sz., 2010, 63(7-8), 247251. [Hungarian]

[22] Klivényi, P., Vécsei, L.: The use of Stalevo in Hungary for patients with Parkinson disease and its effect on the quality of life. [A Stalevo-kezelés magyarországi tapasztalatai és hatása a Parkinson-kórban szenvedő betegek életminőségére.] Ideggyogy Sz., 2008, 61(1-2), 42-48. [Hungarian]

[23] Brodszky, V., Péntek, M., Bálint, P. V., et al.: Comparison of the Psoriatic Arthritis Quality of Life (PsAQoL) questionnaire, the functional status (HAQ) and utility (EQ-5D) measures in psoriatic arthritis: results from a cross-sectional survey. Scand. J. Rheumatol., 2010, 39(4), 303-309.

[24] Meszaros, A., Orosz, M., Magyar, P., et al.: Evaluation of asthma knowledge and quality of life in Hungarian asthmatics. Allergy, $2003,58(7), 624-628$.
[25] Hankó, B., Kázmér, M., Kumli, P., et al.: Self-reported medication and lifestyle adherence in Hungarian patients with type 2 diabetes. Pharm. World Sci., 2007, 29(2), 58-66.

[26] Szende, A., Németh, R.: Health-related quality of life of the Hungarian population. [A magyar lakosság egészségi állapothoz kapcsolódó életminősége.] Orv. Hetil., 2003, 144(34), 1667-1674. [Hungarian]

[27] Szende, A., Janssen, B., Cabases, J.: Self-reported population health: an international perspective based on EQ-5D. Springer Open, 2014.

[28] Dolan, P.: Modeling valuations for EuroQol health states. Med. Care, 1997, 35(11), 1095-1108.

[29] Péntek, M.: Assessment of health, health-related quality of life. In: Gulácsi, L. (ed.): Health economy and technology analysis. [Az egészség értékelése, az egészséggel összefüggő életminőség. In: Gulácsi, L. (szerk.): Egészség-gazdaságtan és technológiaelemzés.] Medicina Könyvkiadó, Budapest, 2012. [Hungarian]

[30] Donaldson, C., Baker, R., Mason, H., et al.: European Value of a Quality Adjusted Life Year. Instrument: Specific Targeted Research Project. Final Publishable Report, 2010. http://research. ncl.ac.uk/eurovaq/EuroVaQ_Final_Publishable_Report_and_ Appendices.pdf

[31] The OECD list of social indicators. OECD, Paris, 1982.

[32] OECD Health Statistics, 2014. http://www.oecd.org/els/ health-systems/oecd-health-statistics-2014-frequently-requested-data.htm

(Baji Petra,

Budapest, Fővám tér 8., 265. szoba, 1093 e-mail: petra.baji@uni-corvinus.hu)

\section{A MAZSIHISZ Szeretetkórház (1145 Budapest XIV., Amerikai út 53-55.) orvos igazgatója álláspályázatot hirdet egy fő belgyógyász szakorvos, vagy közvetlenül szakvizsga előtt álló kolléga részére.}

Gerontológiai szakvizsga, vagy ilyen irányultságú munkatapasztalat, illetve érdeklődés előnyt jelent.

Nyugdijas szakorvos jelentkezését is várjuk, teljes munkaidős foglalkoztatásban.

A pályázatokat a fenti címre, Dr. Deutsch Zsuzsanna orvos igazgató nevére kérjük küldeni.

Telefon: (06-1) 251-9568 • E-mail: drdeutschzs@szeretetkorhaz.hu 